\title{
POTRET NILAI BUDAYA PENGEMBANGAN DESA BURNO SEBAGAI EDUWISATA BERBASIS AGRONURSING
}

\author{
Anggia Astuti, Suhari, Arista Maisyaroh, Musviro, Eko Prasetya W \\ Program Studi D3 Keperawatan Fakultas Keperawatan Universitas Jember \\ Email:
}

\begin{abstract}
ABSTRAK
Perubahan trend wisata di kalangan masyarakat secara luas tidak hanya menjadi hiburan tetapi bagaimana membuat mereka menjadi teredukasi dan mengubah pola hidup menjadi lebih sehat. Pilihan desa wisata menjadi pelopor untuk perubahan gaya hidup sehat, dengan ditunjang potensi alam, iklim dan kesederhanaan hidup yang jauh dari stress menyebabkan desa wisata menjadi pilihan. Namun untuk membentuk eduwisata yang sehat, refererensi masih sangat terbatas. Tujuan penelitian untuk memotret nilai budaya sebagai eduwisata berbasis agronursing sebagai pengembangan model wisata yang sehat. Desain penelitian yang digunakan adalah kualitatif dengan pendekatan analisis konten induktif dengan metode Focus Grups Discussion (FGD) menggunakan pertanyaan semistruktur yang melibatkan 2 kelompok, masing-masing terdiri dari 7 dan 8 orang dengan latar belakang petani pisang, kopi, sapi, kambing, budidaya holtikulra dan industri kecil olahan hasil pertanian di Desa Burno Kecamatan Senduro Kabupaten Lumajang. Data dikumpulkan dan dianalisis dengan menggunakan analisis tematik berdasarkan pendekatan Krueger, R. and Casey, M. Penelitian menghasilkan tiga tema yaitu kebanggaan menjadi petani, melestarikan budaya dan mempertahankan nilai-nilai kebaikan dalam bekerja. Pengembangan potensi desa menjadi eduwisata memiliki nilai-nilai budaya yang harus terpenuhi yaitu tidak membuat perubahan dalam kehidupan masyarakat desa, masyarakat tidak keluar dari rutinitas keseharian mereka dan menonjolkan kearifan lokal yang menjadi potensi besar yang bisa dikembangkan.
\end{abstract}

Kata kunci :nilai budaya, eduwisata desa, agronursing

The current start of changes in tourist trends among the community widely, not only become entertainment but also how to make them become educated and change living patterns to be healthier. The choice of tourism villages being a pioneer for healthy lifestyle changes, with the supported natural potential, climate, and simplicity of living away from stress causes tourism village to be an option, but to form a healthy tourism referees still very limited. The purpose of this research was to capture cultural values as an agronursing-based education and tourism for the development of a healthy travel model. The design of the research used qualitative with an inductive content analysis approach with Focus Groups Discussion (FGD). FGD was conducted using a semistructured question involving two groups, each group consists of seven and eight people with a background of banana farmers, coffee, cows, goats, other vegetable and fruit agriculture and small industrial processed agricultural products in Burno Village, 
Senduro District, Lumajang Regency. Data were collected and analyzed using thematic analysis based on the Krueger, $R$. and Casey, $M$. The research produced three themes, namely pride in being farmers, conserve culture, and maintaining ethical values at work. The development of village potential into tourism has cultural values that must be fulfilled namely not making changes in the life of the village community, the community does not get out of their daily routines and accentuates local wisdom which is a great potential that can we developed

Keywords: cultural values, village education, Agronursing

\section{PENDAHULUAN}

Indonesia sebagai negara agraris memiliki kekayaan alam terutama sumber daya hayati tropis yang tidak hanya sangat beragam tetapi juga unik. Keragaman dan keunikannya diperkuat oleh kekayaan dan keragaman budaya, disamping berperan sebagai sumber pangan dan devisa negara, juga mempunyai daya tarik dalam sektor pariwisata alam (ecotourism) (Winasis, 2016). Menurut pendapat Rero (2011) dalam pengembangan pariwisata, baik pengembangan destinasi pariwisata, maupun pengembangan daya tarik wisata pada umumnya merupakan bagian dari sebuah strategi dalam upaya memajukan, memperbaiki, dan meningkatkan kondisi riil daerah setempat, sehingga memberikan nilai tambah dan bermanfaat bagi msayarakat di sekitar daya tarik wisata merupakan inovasi/program baru dalam perencanaan pembangunan, dalam hal ini dilakukan pengembangan pariwisata yang tidak terlepas dari ciri kegiatan masyarakat pedesaan yang telah ada, baik kondisi potensi desa, potensi fisik, sosial ekonomi dan sosial budaya (Winasis, 2016).

Keberadaan desa wisata saat ini memiliki daya pikat yang baik, bukan saja karena Indonesia terdiri dari beragam tradisi dan kebudayaan, namun kekayaan alam yang terbentang antara desa satu dengan desa yang lain memiliki keunikan dan kekhasan tersendiri (Syah, 2017).

Kriteria suatu desa dapat dikembangan menjadi desa wisata, apabila memiliki beberapa faktorfaktor pendukung antara lain; (1) memiliki potensi produk dan daya tarik, (2) memiliki dukungan sumber daya manusia (SDM), (3) motivasi kuat dari masyarakat, (4) memiliki dukungan sarana dan prasarana yang memadai, (5) mempunyai fasilitas pendukung kegiatan wisata, (6) mempunyai kelembagaan yang mengatur kegiatan wisata, dan (7) ketersediaan lahan/area yang dimungkinkan untuk dikembangkan menjadi tujuan wisata (Utomo,2017)

Pemodelan desa wisata bagi pembangunan pedesaan yang berkelanjutan harus terus secara kreatif mengembangkan identitas atau ciri khas yang baru bagi desa untuk memenuhi tujuan pemecahan masalah yang berkaitan dengan krisis ekonomi daerah pedesaan, semakin bertambah akibat adanya berbagai kekuatan yang rumit, yang menyebabkan baik berkurangnya kesempatan kerja maupun peningkatan kekayaan masyarakat 
desa, salah satu jalan keluar yang dapat mengatasi krisis tersebut adalah melalui pembangunan industri desa wisata skala kecil, sehingga mampu bersaing dan unggul dalam pembangunan daerah pedesaan, dan dalam penciptaan lapangan kerja baru serta peningkatan kesejahteraan masyarakat (Siti Mujanah, 2016).

Akan tetapi penelitian terkait dengan pembentukan desa wisata masih sangat jarang ditemukan, oleh karena itu penelitian ini memiliki tujuan untuk memotret nilai nilai budaya desa untuk dikembangkan menjadi desa wisata yang tetap memperhatikan kearifan lokal serta bertujuan untuk mengedukasi masyarakat untuk bergaya hidup sehat.

\section{METODE PENELITIAN}

Penelitian ini merupakan rancangan deskriptif yaitu potret nilai budaya pengembangan desa Burno sebagai eduwisata berbasis agronursing. Penelitian dilakukan pada bulan Agustus Sampai Oktober 2019 di Desa Burno Kecamatan Senduro Kabupaten Lumajang menggunakan metode focus grup discussion (FGD). Partisipan dalam penelitian ini adalah dua kelompok masyarakat desa, kelompok berdasarkan pengelompokan usia, dimana masing masing kelompok terdiri dari 7 dan 8 orang. Kriteria inklusi pada penelitian ini adalah masyarakat asli Desa Burno, memiliki penghasilan utama dari mengolah sumber daya alam yang ada di Desa Burno.

Prosedur penelitian dilakukan setelah mendapatkan persetujuan penelitian, partisipan mengisi lembar data demografis, dibagi 2 kelompok masing masing terdiri dari 7 dan 8 orang yang mewakili dari berbagai segmen usia diwawancarai tentang pengalaman mereka dalam mengembangkan eduwisata di Desa Burno. Pertanyaan wawancara utama adalah "sebagai pelaku eduwisata di Desa Burno nilai-nilai apa yang Anda pegang dalam pengembangan eduwisata di Desa Burno. Alat pengumpul data dalam penelitian ini adalah rekaman video dan catatan. Masing-masing kelompok diberikan waktu untuk mengekpsresikan ideide mereka secara bebas tentang pengalaman mereka dan pandangan pribadi. Diskusi dijadwalkan per sesi dilakukan selama 60-120 menit. FGD dilakukan masing-masing kelompok selama 2 kali pertemuan. Untuk menjaga validitas dan reliabilitas hasil penelitian, analisis data dilakukan secara mandiri oleh peneliti dan tema didiskusikan sampai terdapat hasil data yang jenuh. Dalam menentukan tema akhir peneliti melakukan juga analisis dengan peer review. Untuk selanjutnya dalam penulisan hasil partisipan disingkat dengan huruf "p", kelompok disingkat dengan huruf "k" dan waktu FGD disingkat dengan FGD. Penelitian ini telah mendapatkan nomor ijin penelitian dari Badan Kesatuan Bangsa dan Politik Kabupaten Lumajang dengan nomor 072/1906/427.75/2019. Analisis data dilakukan setelah semua wawancara kelompok FGD ditanskrip secara verbal dan frasa diperoleh dari data yang dikumpulkan dan diteliti secara berulang untuk memastikan 
konsistensi, kemudian dilakukan pengkodean dan menyusun dalam tema yang dikembangkan. Penelitian ini menggunakan analisis konten induktif dalam melakukan analisis data. Proses analisis data dengan membuat koding secara terbuka dan membuat katagori setelah semua materi tertulis dan dibaca lebih dari sekali untuk dipahami semua aspek dan konten nya, katagori dikelompokkan berdasarkan kesamaan dan ada tiga tema utama yang dihasilkan.

\section{HASIL PENELITIAN}

\section{Gambaran demografi}

\begin{tabular}{llr}
\multicolumn{2}{c}{ Desa Burno } & Kecamatan \\
Senduro Kabupaten & Lumajang \\
merupakan salah satu desa yang \\
secara grafis berada di daerah \\
TNBTS (Taman Nasional Bromo
\end{tabular} Tengger Semeru) yang berada pada ketinggian diatas $700 \mathrm{Mdpl}$, dengan luas wilayah 548.78 Ha.Desa Burno memiliki karakter kawasan yang dapat dikembangkan sebagai kawasan ekowisata, yaitu kondisinya yang masih alami dengan vegetasi yang masih asli dan memiliki banyak potensi kawasan yang dapat dikembangkan.

Desa Burno memiliki potensi unggulan seperti Pisang Mas Kirana, Pisang Agung, selain itu juga terdapat pembuatan pupuk Tricoderma dan Bokasi.Tricoderma dan Bokasi sendiri digunakan sebagai pencegahan penyakit/virus terhadap pisang dan kopi. Hasil perkebunan pisang dapat diolah menjadi keripik pisang dan french Banana. Vegetasi alam yang masih alami digunakan oleh masyarakat Desa Burno untuk berternak sapi sehingga menghasilkan susu sapi dengan kualitas terbaik. Selain sapi, kambing merupakan salah satu hewan ternak unggulan, jenis kambing yang banyak di ternak di Desa Burno meliputi kambing etawa, kambing PE, dan kambing kaligesing.Pemanfaatan hasil kotoran sapi dan kambing dapat dimanfaatkan sebagai biogas dan juga pupuk bagi tanaman petani diladang.

Tabel 1.Karakteristik responden

\begin{tabular}{lc}
\hline $\begin{array}{l}\text { Karakteristik } \\
\text { Responden }\end{array}$ & n \\
\hline Usia & \\
$\leq 29$ tahun & 3 \\
$30-39$ & 4 \\
$40-49$ & 2 \\
$\geq 50$ tahun & 6 \\
Jenis Kelamin & \\
Laki- laki & 13 \\
Perempuan & 2 \\
Pendidikan & \\
Terakhir & \\
SD & 5 \\
SMP & 3 \\
SMA & 3 \\
Strata 1 & 4 \\
Jenis Komoditas & \\
pertanian & \\
/peternakan & \\
Pisang/kopi & \\
sapi & 5 \\
kambing & 4 \\
Industry kecil & 4 \\
\hline
\end{tabular}

Tiga tema yaitu kebanggaan sebagai petani, melestarikan budaya, dan mempertahankan nilai kebaikan dalam bekerja. 


\section{Tema Kebanggaan sebagai petani}

Kebanggaan sebagai petani memiliki arti kesesuaian antara identitas petani (harapan dan aspirasi) dengan kenyataan sehari hari sebagai petani sehingga merasa berbesar hati karena memiliki keunggulan dan keberhasilan dalam hidupnya. Tema ini memiliki tiga sub tema yaitu otonomi, merasa hidup yang bermakna, integritas.

Otonomi merupakan hal dasar yang membuat seseorang merasa bebas dari intervensi pihak lain, karena bisa menentukan sendiri apa yang diinginkan dan terbebas dari campur tangan pihak lain dalam menentukan apa yang harus dilakukan untuk meningkatkan kesejahteraaan nya sebagai petani.. Pernyataan partisipan yang berkaitan dengan hal tersebut dapat dilihat di bawah ini:

"Seneng aq bu jadi petani, iso nentukan sendiri jam kerja nya, hehehehe, mau apa enak kayak bos nya gitu hehehehe" (plkl FGD 1)

"'mau libur ndak ngarit bisa $\underline{\text { bu pokoknya direncanakan }}$ dulu, kermarin nya pakan nya wis dikebeki wis..." (p3kl FGD 1)

"ya kita bu yang mentukan dimana nyari bahan baku yang cocok, soalnya kadang ada ketela pohon yang jelek ndak bagus buat kripik ..."( p6k2FGD 2)

Pernyataan partisipan diatas menggambarkan otonomi dari pekerjaan mereka cukup besar. Kata kata yang digunakan adalah jam kerja nentukan sendiri, mau libur bisa, menentukan sendiri. Arti dari menentukan sendiri adalah memeiliki hak priogratif sendiri terhadap aktivitas kerja yang dilakukan tanpa ada intervensi dari pihak pihak lain nya.

Sub tema kedua adalah merasa hidup yang bermakna yang memiliki pengertian bahwa hidup sebagai petani memiliki arti penting dan mendalam bagi orang lain. Hal ini dapat dilihat dari ungkapan partisipan di bawah ini :

" "seneng bu banyak tamu yang datang belajar ke kita apa aja wis ada yang belajar tentang tunas pisang, tentang ternak kambing, ternak sapi perah dan lain nya juga ..." (p8kl FGD 1)

"Kita itu bu pingin nya banyak orang yang paham tentang apa yang kita lakukan di burno ini, jadinya kan klo banyak tamu kita bisa bagi ilmu ke mereka ......" $(p 4 k 2 F G D 1)$

"alhamdulillah bu, klo dibilang cukup insyaallah cukup buat kami penuhi kebutuhan hidup keluarga dengan tani sama ternak ini ......" ( $p 3 k 2 F G D 2)$

Ungkapan partisipan diatas menyatakan bahwa sebagai seorang petani mereka merasa hidup yang bermakna untuk orang lain, baik dari segi kemanfaatan ilmu atau peran dalam keluarga. Hal ini diungkapkan dengan menggunakan kata- kata 
belajar ke kita, bisa bagi imu dan penuhi kebutuhan keluarga.

Sub tema ketiga dari kebanggaan sebagai petani adalah integritas, yang memiliki makna sifat, atau keadaan yang menunjukkan kesatuan yang utuh sehingga memiliki potensi dan kemampuan yang memancarkan kewibawaan dan kejujuran sebagai petani. Integritas ini menambah kepuasan petani dalam kehidupan mereka. Hal ini terlihat dari pernyataan partisipan di bawah ini

"iya gitu bu kadang onok sing nakal grade $B$ tapi sudah dibilang Grade A, klo kami ndak suka lek koyok ngunu... lek ngomong barang ya grade A ya kita bilang grade A klo grade $B$ ya ndak bilang grade A yooo engkok malah ngerusak pasaran kita sendiri......"( p2k2FGD 1)

"Kita pingin keunggulan kita itu ono ndok produk yg organic, dadine yo mulai dari pupuk, obat kita pakai yang alami kita ngembangkan bokasih dan trikoderma, jadi ndak pakai pestisida wis ......", (p7k1FGD 2)

Pernyataan diatas menunjukkan adanya kebanggaan sebagai petani dengan cara menjaga kejujuran dan meningkatkan kemampuan sebagai petani.

\section{Tema Melestarikan Budaya}

Melestarikan Budaya memiliki arti keteguhan dalam mempertahankan keaslian kebiasaan yang sudah turun temurun diajarkan oleh para sesepuh untuk tetap menjadi petani dalam menjaga kelangsungan hidup: Melestarikan budaya memiliki dua sub tema yaitu autentik dan kecintaan terhadap profesi petani.

Autentik memiliki arti keaslian dari sebuah identitas diri dari petani di daerah lereng gunung. Pernyataan partisipan tentang sub tema ini dapat diihat di bawah ini:

"kita seneng jika ada tamu tapi kita tetep biso aktivitas seperti biasa, yo nang lahan sak bendino yo iso nerima tamu, malah tamu ne ndelok kita nandur pisang, ngerawat pisang ......"( p6klFGD 1)

"meres susu nya sedino ping loro, pagi jam 5 siang jam 2 , lanjut setor nang KUD isuk golek hijauan di hutan tiap harikita seperti itu, jadi mesti ada tamu ya tetep hehehehe tamu nya yang ikut jadwal kita heheheh (sambil tertawa)......"( p2k2FGD 2)

Pernyataan partisipan diatas mengungkapkan bahwa mereka tidak ingin meninggalkan kebiasaan dan aktivitas harian meskiun ada penambahan kegiatan baru untuk memajukan potensi desa menjadi desa wisata.

Sub tema kedua adalah kecintaan terhadap profesi petani yang memiliki arti perasaan suka dan menikmati menjalankan aktivitas sehari hari menjadi petani. Hal ini terlihat dari pernyataan partisipan di bawah ini: 
"lek aq bu lebih seneng pancet ndok burno daripada golek penggaweane laine, teko susu ae loh wis iso nyukupi kebutuhan keluargaku heheheh (sambil tertawa)......"( p3k2FGD 2)

"tani iku enak uripe ayem ndak neko neko... wis bendino koyok ngene sing penting cukup ... “ (plk1FGD 2)

Pernyataan partisipan diatas mengungkapkan bahwa mereka sangat menikmati dan mencitai berprofesi menjadi petani dengan ungkapan senang, ayem, cukup untuk keluarga.

\section{Tema mempertahankan nilai nilai kebaikan dalam bekerja}

Nilai nilai kebaikan dalam bekerja merupakan tema ketiga yang berhasil dieksplorasi dari 2 kelompok FGD. nilai nilai kebaikan dalam bekerja ini memili arti aktifitas yang memperhatikan nilai nilai luhur untuk memberikan manfaat baik untuk diri sendiri atau orang lain. Hal ini dapat dilihat dari kutipan partisipan di bawah ini:

"kita ndak pakai bahan tambahan atau pengawet bu semua nya bahan alamiah “......” " (p5k2FGD 1)

“ klo mau memeras susu ya kita harus bersihkan kandang nya dulu, mandikan sapi nya, lalu kita mandi juga, ambing susu nya dikompres pakai air hangat dulu, jadi semua nya harus bersih pokoknya ......" (p3k1FGD 2) "setiap bersentuhan dengan kambing ya harus cuci tangan sebelum lanjut kegiatan yang lain nya ... “....."” (p3k1FGD 1)

Hasil FGD diatas menyebutkan memperhatikan prinsip prinsip menjaga kebersihan dan bahan alami merupakan nilai nila kebaikan yang mereka lakukan dalam menjalankan aktivitas sehari hari dalam bekerja .

\section{PEMBAHASAN}

\section{Kebanggaan sebagai Petani}

Berdasarkan hasil FGD dan pengamatan yang dilakukan oleh peneliti hampir seluruh partisipan merasa bangga sebagai petani, hal ini berdasarkan adanya otonomi dalam bekerja yang tidak tergantung dengan orang lain. Merasa hidup lebih bermakna dengan bisa memberikan ilmu kepada orang lain dan bermanfaat untuk keluarga dan masyarakat secara umum dengan berprofesi sebagai petani, karena hasil mereka menjadi penopang kehidupan manusia. Integritas menjadi indikator adanya rasa bangga sebagai petani, karena mereka dengan berbuat baik dan jujur akan memberikan kontribusi terhadap peradaban manusia dalam membentuk budaya dalam masyarakat dengan nilai-nilai kebaikan dan kejujuran. Hal ini sejalan dengan penelitian yang dilakukan oleh Astuti (2016) yang mendapatkan hasil seluruh responden petani sepakat bahwa pekerjaan bertani merupakan pekerjaan yang mulia dan mereka merasa bangga sebagai petani, oleh karena itu mereka tetap menjadi petani 
meskipun ada banyak pilihan pekerjaan yang lain nya (Maisyaroh, 2019). Kebanggaan sebagai petani merupakan wujud kesesuaian antara harapan mereka dan kenyataan sehari hari yang mereka lakukan, kebanggaan itu akan tetap tampak apabila mereka dengan senang hati dan kontinyu melakukan pekerjaan tersebut dan tidak merubah mencari pekerjaan yang lain nya (Dessein, J\& Frank Nevens, F, 2007). Hal ini seiring dengan pernyataan partisipan yang mengatakan bahwa mereka ingin mengembangkan desa wisata dengan menonjolkan kegiatan mereka sehari hari sebagai petani dan tidak mau beralih profesi yang lain nya.

\section{Melestarikan Budaya}

Partisipan peserta FGD hampir seluruhnya sepakat bahwa mereka bertani karena mereka mencintai pekerjaan mereka dan bertekad untuk menjaga amanah pendahulu mereka untuk menjaga keaslian desa mereka dan meneruskan pekerjaan sebagai petani untuk menjaga keaslian budaya Desa Burno.Hal tersebut hampir sama ditemukan dalam penelitian yang dilakukan oleh perdana (2013) terhadap masyarakat sedulur singkep, dimana petani melakukan aktivitas kerja dapat memposisikan suatu pandangan yang memiliki nilai luhur, niat, keuletan, dan keterampilan pekerjaan yang jauh dari kebohongan, dan menjunjung tinggi kejujuran melalui rasa setulus hati dalam bercocok tanam dan adanya dukungan melestarikan lingkungan pertanian untuk keberlanjutan masa mendatang, sehingga dapat menjadikan suatu pekerjaan mulia yang dapat memenuhi kebutuhan pangan keluarga dan khalayak.

\section{Mempertahankan Nilai Nilai Kebaikan dalam Bekerja}

Seluruh partisipan sepakat bahwa untuk dapat mengajak orang lain melalui eduwisata maka nilai nilai kebaikan harus tetap dijaga, karena hanya kebaikan yang bisa diterima dan disebarkan ke banyak orang. Nilai nilai ini sudah mendarah daging dalam kegiatan keseharian mereka dalam bekerja, dengan menjaga produk mereka sehat dan menjaga kesehatan mereka dalam bekerja. Nilai nilai ini sejalan dengan prinsip kesehatan. Hal ini sangat sesuai dengan prinsip prinsip kesehatan kerja, dimana dengan mengenali hal-hal yang berpotensi menimbulkan kecelakaan dan penyakit akibat kerja serta tindakan antisipatif terjadinya kecelakaan dan penyakit akibat kerja (Lestari 2007 dalam Maisyaroh, 2019), ditambah lagi dengan produk sehat yang dihasilkan dengan menggunakan bahan alamiah dan menjauhi bahan kimia dalam seluruh proses mulai tanam sampai pengolahan hasil sesuai dengan pola gaya hidup sehat. Wisata sehat telah menjadi pilihan wisata saat ini sedang mengetren dikalangan masyarakat, wisata ini membantu mempromosikan gaya hidup sehat dengan tetap bersantai menikmati berkunjung ke tempat yang baru dan menarik,tetapi juga memberikan manfaat terhadap kesehatan fisik dan jiwa (Emanuela Maria, A., \& Monica Paula, R, 2014). Nilai budaya pengembangan Desa Burno sebagai eduwisata berbasis 
agronursing mempunyai implikasi pada aspek teori dan praktik.

Implikasi teori penelitian ini dapat memberikan gambaran tentang nilai-nilai budaya dalam memperdalam keilmuan, dan pemahaman terkait temuan-temuan terhadap nilai yang yang muncul dan dipahami oleh petani dalam pengembangan Desa Burno sebagai eduwisata berbasis agronursing . Penelitian ini dapat menjadi dasar bagi institusi pendidikan keperawatan untuk mengembangkan kurikulum Eduwisata berbasis agronursing.

Implikasi praktek penelitian ini dapat menjadi dasar bagi perawat dalam pengembangan Desa Burno sebagai eduwisata berbasis agronursing dengan pendekatan budaya yang ada di Desa burno sehingga rasa memiliki terhadap pengembangan eduwisata menjadi lebih besar dan potensi dapat dimaksimalkan dengan baik untuk meningkatkan pendapatan perkapita masyarakat desa Burno.

\section{SIMPULAN}

Masyarakat Desa Burno sebagai petani memiliki nilai-nilai budaya yang perlu dipahami dalam pengembangan Eduwisata berbasis Agronursing. Penelitian ini menghasilkan tiga tema yaitu kebanggaan menjadi petani, melestarikan budaya dan nilai-nilai luhur dalam bertani. Pengembangan potensi desa menjadi eduwisata memiliki nilai-nilai budaya yang harus terpenuhi yaitu tidak membuat perubahan dalam kehidupan masyarakat desa, masyarakat tidak keluar dari rutinitas keseharian mereka dan menonjolkan kearifan lokal yang menjadi potensi besar yang bisa dikembangkan.

\section{SARAN}

Pengembangan eduwisata berbasis Agronursing perlu dilakukan secara berkala sehingga dapat meningkatkan kapasitas dan kapabilitas terbentuknya Eduswisata berbasis Agronursing dengan memperhatikan nilai-nilai budaya dari masyarakat desa sebagai potensi sumber daya manusia yang dominan.

\section{DAFTAR PUSTAKA}

Astuti, N. B. (2016). Sikap Petani Terhadap Profesi Petani: Upaya Untuk Memahami Petani Melalui Pendekatan Psikologi Sosial (Kasus Petani Dikecamatan Pauh, Kota Padang). Agrisep Vol 16 No. 1 Maret 2016, Hal:5966 I 59

Dessein, J and Nevens, F (2007). 'I'm Sad To Be Glad'. An Analysis of Farmers' Pride in Flanders UK Sociologia Ruralis, Vol 47, Number 3, July 2007. ISSN 0038-0199

Emanuela Maria, A., \& Monica Paula, R. (2014). Healthy tourism - a real need in today's challenging society. Journal of Medicine and Life, 7(Spec Issue), 38.

Indreswari, R. K. (2018). Pemberdayaan Masyarakat Berbasis Industri Kreatif Untuk Ekonomi Berdikari Di Desa Rintisan Wisata Pojok Kecamatan Tawangsari 
Kabupaten Sukoharjo. Proceeding SNKPPM , 132-135.

Krueger, R. and Casey, M. (2009) Focus Groups: A Practical Guide for Applied Research.Sage Publications, Thousand Oaks, CA.

Maisyaroh, A (2019) Buku Ajar Agronursing.Bondowoso:

CV KHD Production

Perdana, A.S.(2013)Optimalisasi Etos Kerja Petani Sedulur Sikep sebagai Upaya Penanggulangan Krisis Pangan

OptimizationofFarmersWorkE thosSedulurSikep asPreventiveEffortofFoodCri sis.Jurnal PKS Vol 12 No3 September 2013, hal 215224

Siti Mujanah, T. R. (2016). Strategi Pengembangan Desa Wisata Di Kawasan Hinterland Gunung Bromo Jawa Timur. Untag Surabaya, 3352.

Speziale,\& Carpenter. (2007). Qualitative Research in Nursing: Advancing, the humanistic Inperative (3 ed.). Philapdhelpia: Lippincott Williams \& Wilkins.

Syah, F. (2017). Strategi Mengembangkan Desa Wisata. 355-341.

Utomo,Joko Slamet.2017. Strategi Pengembangan Desa Wisata Di Kecamatan Karangploso Kabupaten Malang.NeoBis.Volume 11 Nomor 2 Desember 2017

Winasis, A. D. (2016). Efektivitas Program Pengembangan
Desa Wisata Melalui Kelembagaan Dalam Peningkatan Sumber Daya Alam (SDA). JISIP : Jurnal Sosial dan Ilmu Politik, 12-16. 